\title{
A Review of the Biology and Control of Whitefly, Bemisia tabaci (Hemiptera: Aleyrodidae), with Special Reference to Biological Control Using Entomopathogenic Fungi
}

\author{
Ibrahim Sani ${ }^{1,2}$, Siti Izera Ismail ${ }^{1,3} \oplus^{\oplus}$, Sumaiyah Abdullah ${ }^{1}{ }^{\complement}$, Johari Jalinas ${ }^{4}(\mathbb{D}$, \\ Syari Jamian ${ }^{1,3, *}$ and Norsazilawati Saad ${ }^{1, *}$ \\ 1 Department of Plant Protection, Faculty of Agriculture, Universiti Putra Malaysia, Serdang 43400, Malaysia; \\ sani.ibrahim@umyu.edu.ng (I.S.); izera@upm.edu.my (S.I.I.); sumaiyah@upm.edu.my (S.A.) \\ 2 Department of Biology, Faculty of Natural and Applied Sciences, Umaru Musa Yar'adua University, P.M.B., \\ Katsina 2218, Nigeria \\ 3 Laboratory of Climate-Smart Food Crop Production, Institute of Tropical Agriculture and Food \\ Security (ITAFoS), Universiti Putra Malaysia, Serdang 43400, Malaysia \\ 4 Department of Biological Sciences and Biotechnology, Faculty Science \& Technology, \\ Universiti Kebangsaan Malaysia, Bangi 43600, Malaysia; johari_j@ukm.edu.my \\ * Correspondence: syari@upm.edu.my (S.J.); norsazilawati@upm.edu.my (N.S.); Tel.: +60-18-2474874 (N.S.)
}

Received: 17 August 2020; Accepted: 8 September 2020; Published: 10 September 2020

Simple Summary: The whitefly, Bemisia tabaci, is considered one of the most destructive insect pests of vegetables and ornamental crops globally. Synthetic chemical pesticides are mainly used to control B. tabaci, however, their extensive usage has led to a series of detrimental concerns to human health and environmental contamination. It is therefore of significant interest to develop a safer and eco-friendly alternative for controlling $B$. tabaci. Here, we review the use of entomopathogenic fungi as a proven, biologically sustainable method to effectively control $B$. tabaci. The development of entomopathogenic fungi in an integrated pest management strategy against $B$. tabaci can reduce our reliance on chemical pesticides, and help us to secure food safety while preserving nature.

\begin{abstract}
Whitefly, Bemisia tabaci (Gennadius) (Hemiptera: Aleyrodidae), consists of genetically diverse species known to cause significant destruction in several crops around the world. Nymphs and adults of $B$. tabaci cause damage to plants during feeding, and they can act as a virus vector, thus causing significant yield loss to crops in the tropical and subtropical regions. Chemical pesticides are widely used to control B. tabaci due to their immediate action, but this approach has several drawbacks including food safety issues, insecticide resistance, environmental pollution, and the effect on non-target organisms. A biological control agent using entomopathogenic fungi (EPF) has therefore been developed as an alternative against the conventional use of chemical pesticides in an integrated pest management (IPM) system to effectively control B. tabaci. It is apparent from this review that species of hyphomycetes fungi are the most common EPF used to effectively control $B$. tabaci, with the second instar being the most susceptible stage of infection. Therefore, this review article focuses specifically on the control of B. tabaci with special emphasis on the use of EPF as biological control agents and their integration in IPM.
\end{abstract}

Keywords: biological control; Bemisia tabaci; entomopathogenic fungi; host plant; whitefly 


\section{Introduction}

Of the 1556 species of whiteflies recorded in the world, B. tabaci remains one of the most economically important pests of vegetable and ornamental crops worldwide [1,2]. The insect feeds on several solanaceous and ornamental crops, including brinjal, chili, cotton, okra, potato, tomato, and tobacco $[3,4]$. The economic damage caused by $B$. tabaci ranges from mild to catastrophic with global annual loss reaching up to billions of USD in many crops [5-7]. B. tabaci adults are minute insects (usually 1 to $3 \mathrm{~mm}$ in length) that feed and oviposit in large quantities on the underside of leaves [8].

Bemisia tabaci may decrease the rate of photosynthesis in plants through the excretion of honeydew during feeding, besides being able to transmit a large number of plant pathogenic viruses including begomoviruses, carlaviruses, criniviruses, ipomoviruses, and torradoviruses [9-13]. Chemical pesticides are the most widely used method to control B. tabaci infestation. Chemical pesticides with a similar mode of action, such as neonicotinoids and insect growth regulators are conventional means to manage B. tabaci [14]. The excessive use of these chemicals has led to numerous problems, such as health risk to users and consumers of farm produce, the development of pest resistance, and the destruction of non-target organisms. In recent years, researchers have shown an increasing interest in using biological control agents including entomopathogenic fungi (EPF) as an alternative to chemical control measures [15]. Over the last five decades, biological control measures have been successfully used to control whiteflies in a protected environment [16].

In the integrated pest management (IPM) system, EPF have long been recognized as the natural enemies of the insect population [17]. Species of EPF from several genera have been demonstrated to cause natural mortality of the $B$. tabaci population, with more than 20 species identified to be effective against this insect [5,18-20]. Species such as Beauveria bassiana, Metarhizium anisopliae, Isaria fumosoroseus, Ashersonia spp., and Verticillium lecanii are the most common EPF with potentials as biocontrol agents for B. tabaci [21-24]. EPF are known to infect and kill all life stages of B. tabaci [25]. This paper is therefore intended to discuss the management of $B$. tabaci, with special reference to biological control using EPF as a component of an IPM system.

\section{Taxonomy, Origin, and Distribution of Whitefly, B. tabaci}

Bemisia tabaci was first reported and named Aleyrodes tabaci by Gennadius in 1889, as a pest of tobacco in Greece. Currently, it is distributed worldwide inhabiting every continent of the world except Antarctica $[1,6,26]$. In contrast, some European countries, such as Finland, Sweden, the Republic of Ireland, and the United Kingdom, are still yet to report the existence of B. tabaci [27].

Whitefly taxonomy is based exclusively on puparial characteristics; however, very little taxonomic information can be found on non-puparial life stages [28]. Sexual dimorphism in these puparia contributes to existing knowledge of the whitefly's taxonomic tools of identification, development, reproductive potential, and management [29]. The family Aleyrodidae is divided into three subfamilies: Udamoselinae, Aleyrodinae, and Aleurodicinae [30,31].

In recent years, important progress has been made at the taxonomic level based on the analysis of the mitochondrial cytochrome oxidase subunit I ( $\mathrm{mt} \mathrm{COI}$ ) gene, with at least 43 species complexes of B. tabaci identified [26,30,32-34]. The Middle East-Asia Minor 1 (MEAM1) and Mediterranean (MED) complexes (previously known as B biotype and B. argentifolii, and Q biotype, respectively) are considered the most invasive species with a broad host range of plants $[1,32,35]$. The nature of their broad host range and the global trade of $B$. tabaci host plants may have contributed to their worldwide distribution [32].

\section{Biology of Whitefly, B. tabaci}

Whiteflies have a characteristic life cycle of six stages: the egg, four immature stages (nymphal instars), and the adult stage [1]. Temperature, relative humidity, and host plants are the main factors that greatly influence the life cycle of whitefly species [36-38]. Bemisia tabaci deposit eggs on the 
upper and lower leaf surfaces of plants, and the number of eggs deposited is significantly affected by temperature, with $28^{\circ} \mathrm{C}$ being the most favorable for B. tabaci production [36]. Eggs laid are pear-shaped (approximately $0.2 \mathrm{~mm}$ long), with a gleaming white color that darkens over time, and usually incubate for about 5-9 days depending on the host species, temperature, and humidity [27,39]. Soon after hatching, the first instar (crawler) travels to a short distance until it successfully probes the leaf to feed on the phloem sap before undergoing three more nymphal instar stages (second, third, and fourth) [40].

During the second instar stage, the whitish-yellow nymphs turn yellowish and dome-shaped after feeding. The pale yellow freshly molted third instar nymphs, however, gradually turn dark yellow and more flattened in shape after feeding [41]. The fourth instar nymphs have a yellowish-white color with large eyes visible through the integument; this stage is also known as the "pupal" stage or "red-eye nymph" $[1,39,41]$.

Fully developed adults of $B$. tabaci emerge from the dorsal surface of the pupal case through an inverted " $\mathrm{T}$ "-shaped slit [41]. An adult is yellow-bodied with a pair of white wings that form an inverted V-shape covering the thorax and abdomen. The abdomen of a B. tabaci female is large and round-shaped, while that of the male is pointed [1,42]. The entire life cycle of $B$. tabaci from egg to adult takes approximately 16 to 31 days, with some differences between the duration of each stage depending on the host plants used to rear them $[38,43]$. The $Q$ biotype of B. tabaci has been found to have a shorter life cycle and longer adult longevity than the B biotype [44].

\section{Damage and Losses Caused by B. tabaci}

Bemisia tabaci can cause significant economic losses to crops by causing damage to the host plants during feeding through secretion of honeydew and transmission of plant viruses [45]. Both nymphs and adults of B. tabaci cause damage by inserting their mouthparts into the plants during feeding and by transmitting a large number of viruses that can severely damage susceptible plants species [27].

\subsection{Feeding Damage}

It has been found that B. tabaci nymphs can inject enzymes that cause changes in plant physiology, leading to irregular ripening of fruit and retarded internal coloration [40]. The honeydew excreted by $B$. tabaci provides a medium for the growth of sooty mold on the leaves and fruits, thus reducing photosynthetic activities, which could negatively affect the quality of farm produce [1,39]. In addition, the feeding of B. tabaci on leaves can cause yellowing and crumpling, which subsequently results in stunted plant growth and deformed fruits [3].

\subsection{Bemisia tabaci as a Virus Vector}

More than 200 plant viruses are able to be transmitted by B. tabaci, with the majority of these viruses belonging to the genera Begomovirus, Carlavirus, Crinivirus, Ipomovirus, and Torradovirus [46-48]. Some of the most vulnerable crops to these viruses are cassava, cotton, cowpea, cucurbits, crucifers, eggplants, tobacco, tomato, potato, soybean, sweet potato, okra, lettuce, pea, bean, pepper, poinsettia, and chrysanthemum [41,46]. Of all the viruses transmitted by B. tabaci, begomoviruses are well known as the leading cause of yield losses in crops, ranging from $20-100 \%$ and losses worth millions of dollars [27].

Cassava mosaic and cassava brown streak are destructive viral diseases of cassava in Africa spread by B. tabaci, affecting approximately half of cassava plants in the country, with annual yield losses of more than 1 billion USD [49]. Several different begomovirus species, such as Cotton leaf curl Burewala virus (CLCuBuV), Cotton leaf curl Multan virus (ClCuMuV), and Cotton leaf curl Kokhran virus $(\mathrm{CLCuKoV})$, cause cotton leaf curl disease complex, which is another example of whitefly-transmitted viruses causing losses amounting to millions of US dollars annually throughout the world, making it the most devastating global disease of cotton [7,50]. In addition to cassava and cotton, global tomato production has also been severely affected by whitefly-transmitted begomoviruses, particularly the species Tomato yellow leaf curl virus (TYLCV) [51]. 
The method of transmission provides knowledge about the periods of virus acquisition and inoculation, which can be used to develop effective management strategies [52]. Plant viruses, such as criniviruses, carlaviruses, ipomoviruses, and torradoviruses, are transmitted in a semi-persistent manner, while the begomoviruses are transmitted in a persistent circulative manner [52-55]. Semi-persistent transmission of viruses usually requires at least 15 min of acquisition access with a retention time of up to days in the foregut $[52,56]$. In contrast, several hours are required for acquisition access in the persistent transmission, with retention time in the hemolymph of up to the entire life of the vector [9,55]. In the persistent transmission mode, virus moves from the foregut and into the hemolymph through the midgut of $B$. tabaci before being transported into salivary glands to be egested with saliva into the plant tissues [56].

\section{Control and Management of Whitefly}

IPM is an internationally recognized approach to pest control and is intended to reduce ecological and health damage caused by chemical pesticides. The IPM program for B. tabaci includes biological control, crop plant resistance, physical and mechanical methods, and using selective chemical pesticides when necessary [57].

Host plant resistance to whiteflies has been successfully developed due to the growing concern over the increasing use of synthetic chemical pesticides. Cultivars from different varieties of cotton, tomato, and other field crops have been screened against B. tabaci and many other sap-sucking insects [58-62]. However, the selection and development of resistant cultivars against whitefly-transmitted viruses in breeding programs are quite challenging, because there is a need to screen and inoculate large numbers of plants to select genotypes with resistance genes [9].

Physical and mechanical methods are techniques emphasizing the creation of unfavorable environments for pests, which include the removal of pest breeding sites and the use of healthy seedlings and resistant varieties [63]. Cultural methods such as crop rotation could increase host periods or reduce intercrop migrations through careful consideration of the types and special arrangement of planted crops, thus, ultimately leading to the control of the B. tabaci population [11]. The application of an electric field screen to greenhouse windows can prevent the entry of whitefly, but requires the presence of a guard at the greenhouse entrance area $[64,65]$.

Based on the principle of IPM, pesticides should be the last choice for farmers to use when other options are not successful against the infestation of pests in crops [66]. Over the past two decades, insecticides, including nicotinoids and insect growth regulators, have demonstrated physical and immediate action in controlling $B$. tabaci and other pest-sucking insects $[67,68]$. Foliar applications of systemic insecticides in the neonicotinoid class such as clothianidin, dinotefuran, imidacloprid, thiamethoxam, chlorantraniliprole, spinosad, and flupyraifurone can provide sufficient control of whitefly $[14,69,70]$. The effect of chemical pesticides on the non-target organism, environmental contamination, and resistance of insect pests have led to research on biological control agents as alternative control measures. B. tabaci can be effectively controlled by integrating multiple biological control agents such as parasitoids, predators, and EPF [45,71-76].

There are at least 115 species of whitefly parasitoids belonging to 23 genera in five families: Aphelinidae, Azotidae, Encyrtidae, Signiphoridae (Chalcidoidea), and Platygastridae (Platygastroidea) [77]. Two genera, Encarsia and Eretmocerus in the order Hymenoptera, are the most well-known whitefly parasitoids found throughout the world, while others are specific to different continents [78]. These two parasitoids have been reported to significantly lower the population of B. tabaci via parasitism and host feeding [79-81]. Moreover, there are approximately 150 arthropod species currently described as predators of whiteflies, and the majority of them are ladybird beetles, predaceous bugs, lacewings, phytoseiid mites, and spiders [79]. The biological control study of predators reported by Nomikou et al. [82] showed that two phytoseiid species, Euseius scutalis (Athias-Henriot) and Typhlodromips swirskii (Athias-Henriot), can significantly suppress B. tabaci population on a single plant. 


\section{Biological Control of B. tabaci with Entomopathogenic Fungi}

$\mathrm{EPF}$, an important group of biological control agents for whiteflies, other sap-sucking pests, and pests with chewing mouthparts, play a key role in the natural mortality of whitefly populations, as they can directly infect insects through the cuticle [5,83]. There are approximately 700 species of EPF belonging to the group Laboulbeniales and Pyrenomycetes (phylum Ascomycota), Hyphomycetes (phylum Deuteromycota), and Zygomycetes (phylum Zygomycota) [84]. Most of the EPF currently being studied belong to the class Entomophthorales of the phylum Zygomycota and Hyphomycetes of the phylum Deuteromycota [76].

Based on previous research findings, EPF can be isolated from insect cadavers or soil and can be grown in artificial media $[19,85,86]$. Solid-state, liquid-state, and di-phasic fermentation can be used for large-scale production of EPF by using conidiophores or conidia and hyphae on a granular substrate [87]. The spray and dip application is the most common method used in controlling B. tabaci, with many promising results (Table 1). Various bioassay methods have been developed to evaluate the efficacy of EPF, and the majority of them were applied in the form of either spraying or dipping on B. tabaci [20].

Common species of EPF (B. bassiana, M. anisopliae, and I. fumosorosea) with potential importance in biological control have been commercially produced and documented [88,89]. EPF that infect and kill all developmental stages of the whitefly species complex are mostly derived from the genera Verticillium, Isaria, and Aschersonia [25]. Most of the EPF involved in B. tabaci control studies were species from the following genera: Aschersonia, Beauveria, Isaria (Paecilomyces), Lecanicillium (formerly Verticillium), and Metarhizium [1]. Moreover, it has been recently reported that Clonostachys rosea has a pathogenic effect on the fourth instar nymphal and adult stages of B. tabaci [90].

Biological control of B. tabaci using EPF is summarized in Table 1. Overall findings from previous studies indicated that all species of EPF were pathogenic to B. tabaci, with the second instar stage being the most susceptible to EPF infection. Species from the genus Aschersonia have long been used for controlling whiteflies and other related greenhouse insects in the environment, with high relative humidity and moderate temperatures [5,91]. The application of Aschersonia aleyrodis to control B. tabaci is a promising EPF candidate, which has been proved effective in parasitizing whiteflies [92]. The effectiveness of $A$. aleyrodis isolates tested against second, third, and fourth instar of MEAM1 B. tabaci under laboratory and greenhouse conditions showed greater than $50 \% \mathrm{~B}$. tabaci mortality for seven days [24]. The survival rate of the first, second, and third instar nymphs of $B$. tabaci can be significantly reduced through the application of $A$. aleyrodis isolate (Aa005) under glasshouse conditions [93]. A pathogenic strain of A. aleyrodis (Aa-J18) could kill nymphs and adults of $B$. tabaci with a mortality of up to $99 \%$, as reported by Prayogo and Bayu [94].

Beauveria bassiana (Balsamo-Crivelli) Vuillemin is one of the most commonly encountered $\mathrm{EPF}$, and has been commercially developed as a microbial insecticide to control B. tabaci [1,95]. Zafar et al. [96] applied three different isolates (Bb-01, Bb-08, and Bb-10) of B. bassiana against eggs and the second nymphal instar of B. tabaci on four host plants (Gossypium hirsutum, Lycopersicum esculentum, Solanum melongena, and Capsicum annum). The results showed a significant reduction of B. tabaci eggs and nymphs. Meanwhile, Prithiva et al. [97] demonstrated the effectiveness of three formulations (oil formulation, talc formulation, and crude formulation) of B. bassiana isolate against $B$. tabaci on tomato under microplot conditions. The study showed a reduction in population over control, with the oil formulation being the most effective against $B$. tabaci. The interaction of $B$. bassiana with other biological control agents, such as Bacillus thuringiensis for the biological control of $B$. tabaci, were shown to have an antagonistic effect, and mortality greater than 50\% was observed over a period of 7 days [98]. A combination of bacterial biosurfactant with two EPF, Cordyceps javanica and B. bassiana, has recently been found to cause $100 \%$ mortality of the third instar nymphs of B. tabaci within 4 days [99]. Likewise, the combination of B. bassiana and some plant extracts such as neem have shown increased mortality of B. tabaci [100-103]. 
Isaria fumosoroseus (Paecilomyces fumosoroseus) is one of the most important natural enemies of whiteflies, and it can cause an epizootic in B. tabaci in greenhouse and open field environments [104]. Currently, I. fumosoroseus is globally distributed and can infect a broad range of pests in agricultural and forest areas [105]. Commercial demand to investigate bioproducts based on I. fumosoroseus, due to its capacity to cause natural epizootics on several insect pests, is therefore compelling [106]. Although many studies on the potential of I. fumosoroseus against B. tabaci have been carried out $[6,21,107,108]$, they have been largely focused on the mortality and infections of nymphs and adults of $B$. tabaci (Table 1) [104]. The efficacy of I. fumosoroseus in immediate control of the B. tabaci population can be significantly improved by adding synergistic chemicals, such as imidacloprid and thiamethoxam [109].

Lecanicillium lecanii, also known as L. muscarium (formerly known as $V$. lecanii), is one of the most important commercialized EPF, and has long been used to control greenhouse insect pests, including B. tabaci [110]. It has been proved to be pathogenic to all developmental stages of $B$. tabaci, with the most susceptible stage of infection occurring at the second instar nymph stage [1,110]. An experiment was conducted to determine the pathogenicity of L. lecanii and other EPF B. bassiana, M. anisopliae, and $M$. rileyi against $B$. tabaci. Isolates of $L$. lecanii were found to be the most virulent among all the fungal isolates tested $[23,111]$. Compatibility experiments of $L$. lecanii and other chemical insecticides such as imidacloprid, buprofezin, and teflubenzuron showed promising outcomes in reducing the population of different stages of B. tabaci [112-114].

Metarhizium anisopliae was first discovered to be effective against the greenhouse whitefly, Trioleurodes vaporariorum [115]. However, it has recently been shown that M. anisopliae can potentially infect all developmental stages of different whitefly species [116,117]. The efficacy of five M. anisopliae strains (PR1, GT2, TFFH3, GJ4, HSAH5) against B. tabaci infesting S. melongena showed lethal infections of $B$. tabaci in a dosage response assay, whereby the infectivity rate for the second nymphal instar was 12 times higher than the fourth instar upon inoculation with strain GJ4 [118]. The pathogenicity of six isolates of M. anisopliae was tested on the B. tabaci $Q$ biotype, where the results showed greater than $50 \%$ mortality in all the six isolates [119]. However, higher mortality of B. tabaci $(97 \%)$ was observed under osmotic conditions upon infection with M. anisopliae isolated from Coptotermes gestroi (Rhinotermitidae: Isoptera) [120]. 
Table 1. Summary of control methods of B. tabaci using entomopathogenic fungi (EPF).

\begin{tabular}{|c|c|c|c|c|}
\hline Species & Bioassay Method & Significant Effects/Results & $\begin{array}{l}\text { Country Where Work } \\
\text { Was Conducted }\end{array}$ & Ref. \\
\hline $\begin{array}{l}\text { Aschersonia } \\
\text { aleyrodis }\end{array}$ & $\begin{array}{l}\text { Second and third instars on eggplant leaves were } \\
\text { sprayed with fungal spores at } 1 \times 10^{7} \text { conidia } / \mathrm{mL} \text {. }\end{array}$ & $\begin{array}{l}\text { Mortality: } \\
\text { Second instar: } 71.21 \% \\
\text { Third instar: } 69.31 \% \\
\text { Pupae: } 53.36 \% \\
\text { LC }_{50} \text { : } \\
\text { Second instar: } 7.93 \times 10^{6} \text {; third instar: } 1.08 \times 10^{7} \text {; pupae: } \\
1.56 \times 10^{7} \text { conidia } / \mathrm{mL} \\
\mathrm{LT}_{50}: 4.60 \text { days for second instar. }\end{array}$ & China & [24] \\
\hline A. aleyrodis & $\begin{array}{c}\text { First, second, and third instars on eggplant were } \\
\text { sprayed with spores at } 1 \times 10^{7} \text { conidia/mL on } \\
\text { eggplant leaves. }\end{array}$ & $\begin{array}{l}\text { The survival of first, second, and third nymphal instars was } \\
\text { significantly affected. }\end{array}$ & China & [93] \\
\hline A. aleyrodis & $\begin{array}{l}\text { Eggs; first, second, third, fourth instars; and adults } \\
\text { on the leaves of soybean were sprayed with } \\
1 \times 10^{6} \text { conidia } / \mathrm{mL} \text {. }\end{array}$ & $\begin{array}{l}\text { The highest mortality }(99 \%) \text { was observed for the first, second, } \\
\text { and third instars and the lowest mortality in the adult stage. } \\
\mathrm{LD}_{50}: 6-7 \times 10^{6} \text { conidia/mL } \\
\mathrm{LT}_{50}: 3.50-3.75 \text { days for nymph stage; } 4.50 \text { days for adults. }\end{array}$ & Indonesia & [94] \\
\hline A. placenta & $\begin{array}{l}\text { First, second, and third instars on tomato were } \\
\text { sprayed with } 1.5 \mathrm{~mL} \text { of fungal suspension. }\end{array}$ & $\begin{array}{l}\text { Mortality ranged from } 93 \% \text { to } 100 \% \text {. } \\
\mathrm{LD}_{50} \text { and } \mathrm{LD}_{90} \text { values decreased with time and increased with } \\
\text { instar. } \\
\mathrm{LT}_{50} \text { values decreased with conidial concentrations. }\end{array}$ & China & [121] \\
\hline $\begin{array}{c}\text { Beauveria } \\
\text { bassiana }\end{array}$ & $\begin{array}{l}\text { Eggs and nymphs were sprayed with different } \\
\text { concentrations on plant leaves of cotton, tomato, } \\
\text { eggplant, and bell pepper. }\end{array}$ & $\begin{array}{l}\text { Most effective isolate (Bb-01) on cotton mortality: } \\
\text { eggs: } 65.30 \% \\
\text { nymphs: } 88.82 \% \\
\text { LC }_{50} \text { value: } 2.4 \times 10^{7} \text { spores } / \mathrm{mL} \mathrm{LT}_{50} \text { : lowest on cotton, } 5.40 \text { days }\end{array}$ & Pakistan & [96] \\
\hline B. bassiana & $\begin{array}{l}\text { Nymphs and adults on tomato leaves were } \\
\text { sprayed with different formulations of } 10^{8} \\
\text { spores } / \mathrm{mL} \text {. }\end{array}$ & $\begin{array}{l}\text { Reduction of the population over control in formulations: } \\
\text { Oil: } 45.86 \% \text {. } \\
\text { Talc: } 29.62 \% \text {. } \\
\text { Crude: } 21.63 \% \text {. }\end{array}$ & India & [97] \\
\hline B. bassiana & $\begin{array}{c}\text { Eggs and first, second, third, and fourth instars } \\
\text { were immersed in } 1 \mathrm{~mL} \text { of conidia suspension for } \\
10 \mathrm{~min} .\end{array}$ & $\begin{array}{l}\text { First and second instars were more susceptible than the third and } \\
\text { fourth instars. Nymphs were highly susceptible compared } \\
\text { to eggs. }\end{array}$ & Saudi Arabia & [95] \\
\hline
\end{tabular}


Table 1. Cont

\begin{tabular}{|c|c|c|c|c|}
\hline Species & Bioassay Method & Significant Effects/Results & $\begin{array}{l}\text { Country Where Work } \\
\text { Was Conducted }\end{array}$ & Ref. \\
\hline B. bassiana & $\begin{array}{l}\text { Fourth instars from cucumber, tomato, melon, } \\
\text { green pepper, potato, eggplant, marrow, cabbage, } \\
\text { bean, and cotton plants were immersed in } \\
1.0 \times 10^{7} \text { conidia } / \mathrm{mL} \text { for } 10 \mathrm{~s} \text {. }\end{array}$ & $\begin{array}{l}\text { Mortality and average survival time after } 8 \text { days of inoculation } \\
\text { were significantly influenced by the host plants. Mean mortality } \\
\text { ranged between } 52.3 \pm 7.3 \text { for nymphs reared on cotton and } \\
91.8 \pm 5.8 \text { for nymphs reared on cucumber. }\end{array}$ & Spain & [122] \\
\hline B. bassiana & $\begin{array}{l}\text { Adult B. tabaci ( } 2-3 \text { days old) on cotton were } \\
\text { sprayed with three concentrations }\left(1 \times 10^{3}, 1 \times 10^{5} \text {, }\right. \\
\left.\text { and } 1 \times 10^{7} \text { spores } / \mathrm{mL}\right) \text { of } 1 \mathrm{~mL} \text { of fungal } \\
\text { suspension. }\end{array}$ & $\begin{array}{l}\text { Mortality recorded at the lowest dose }\left(1 \times 10^{3} \text { spores } / \mathrm{mL}\right) \text { was } \\
11 \% \text {, while the highest percentage mortality }(56 \%) \text { was recorded } \\
\text { at a high dose of } 1 \times 10^{7} \text { spores } / \mathrm{mL} \text {, and the recorded natural } \\
\text { mortality was only } 5 \% \text {. }\end{array}$ & Egypt & [123] \\
\hline Isaria spp. & $\begin{array}{l}\text { Second, third, and fourth instars were sprayed } \\
\text { with spore concentrations in clip-screen cages on } \\
\text { sweet potatoes. }\end{array}$ & $\begin{array}{l}\mathrm{LC}_{50} \text { and } \mathrm{LT}_{50} \text { values when exposed to } 1000 \text { spores } / \mathrm{mm}^{2}: \\
\mathrm{LC}_{50}: \text { second instar: } 72-118 \text { spores } / \mathrm{mm}^{2} \text {; third instar: } 166-295 \\
\text { spores/mm² fourth instar: } 166-295 \text { spores } / \mathrm{mm}^{2} \\
\mathrm{LT}_{50} \text { : second instar: } 3 \text { days; third instar: } 4 \text { days. }\end{array}$ & USA & [124] \\
\hline I. fumosoroseus & $\begin{array}{l}\text { Eggs and first, second, third, and fourth instars on } \\
\text { eggplants were dipped in conidia suspension } \\
\qquad\left(1 \times 10^{6} \text { conidia/mL }\right) \text { for } 2-3 \mathrm{~s} \text {. }\end{array}$ & $\begin{array}{l}\text { Most effective isolate (UPM isolate) mortality: } \\
\text { Eggs: } 91 \% \\
\text { Second instar: } 90 \% \\
\text { Third instar: } 86 \% \\
\text { Fourth instar: } 89 \% \\
\mathrm{LT}_{50}: 3.94 \text { to } 6.28 \text { days. }\end{array}$ & Malaysia & [108] \\
\hline I. fumosoroseus & $\begin{array}{l}\text { First, second, and third instars on cucumbers were } \\
\text { sprayed with spores at } 1 \times 10^{7} \text { conidia } / \mathrm{mL} \text {. }\end{array}$ & $\begin{array}{l}\text { The second instar was the most susceptible life stage with } \\
\text { mortality rate at } 83 \% \text { after } 7 \text { days of application. }\end{array}$ & China & [125] \\
\hline I. fumosoroseus & $\begin{array}{l}\text { Second instars on eggplants were dipped in five } \\
\text { different concentrations } \\
\left(1 \times 10^{3}, 1 \times 10^{4}, 1 \times 10^{5}, 1 \times 10^{6}, 1 \times 10^{7} \text { conidia/mL }\right) \\
\text { for } 20 \mathrm{~s} \text {. }\end{array}$ & $\begin{array}{l}\text { LC }_{50} \text { values: } 1.10 \times 10^{4} \text { conidia/mL after } 12 \text { days of treatment. } \\
\text { At a concentration of } 1 \times 10^{7} \text { conidia/mL, minimum average } \\
\text { longevity and number of progenies produced were } 9 \text { days and } \\
10.92 \text { eggs/female, respectively, as compared to } 16.3 \text { days and } \\
83.67 \text { eggs/female for the control. }\end{array}$ & China & [104] \\
\hline $\begin{array}{l}\text { Lecanicillium } \\
\quad \text { lecanii }\end{array}$ & $\begin{array}{l}\text { Second instars on five host plants were sprayed } \\
\text { with } 10^{7} \text { conidia } / \mathrm{mL} \text {. }\end{array}$ & $\begin{array}{l}\text { The highest mortality was recorded in all host plants: } \\
\text { Laboratory conditions: nymphal mortality: }>90 \% \\
\text { Glasshouse conditions: nymphal mortality: } 81 \% \text {. }\end{array}$ & United Kingdom & [110] \\
\hline L. lecanii & $\begin{array}{l}\text { Toxin emulsion was applied to female adult } \\
\text { B. tabaci on the tomato plants. }\end{array}$ & $\begin{array}{l}\text { The toxin reduced the hatching of whitefly eggs, the survival rate } \\
\text { of the nymphs, and the emergence and fecundity of the progeny } \\
\text { adults. }\end{array}$ & China & [126] \\
\hline
\end{tabular}


Table 1. Cont

\begin{tabular}{|c|c|c|c|c|}
\hline Species & Bioassay Method & Significant Effects/Results & $\begin{array}{l}\text { Country Where Work } \\
\text { Was Conducted }\end{array}$ & Ref. \\
\hline L. muscarium & $\begin{array}{l}\text { First, second, third, and fourth instars on tomato } \\
\text { and verbena plants were sprayed with a fungal } \\
\text { suspension }\left(10^{7} \text { spores } / \mathrm{mL}\right) \text {. }\end{array}$ & $\begin{array}{l}\text { First and second instar nymphs were more susceptible to } \\
\text { L. muscarium than the third and fourth instar nymphs. }\end{array}$ & United Kingdom & [127] \\
\hline $\begin{array}{l}\text { Metarhizium } \\
\text { anisopliae }\end{array}$ & $\begin{array}{l}\text { Second instar nymphs were sprayed with } 10^{7} \\
\text { spores/mL of three vegetable oil formulations. }\end{array}$ & $\begin{array}{l}\text { The highest mortality was observed with sunflower oil followed } \\
\text { by olive oil and maize oil formulations. }\end{array}$ & Argentina & [2] \\
\hline M. anisopliae & $\begin{array}{l}\text { Second instar nymphs on eggplants were dipped } \\
\text { into } 10^{8} \text { conidia/mL for } 10 \mathrm{~s} .\end{array}$ & $\begin{array}{l}\text { Mortality caused by two isolates under osmotic conditions was } \\
83.9 \% \text { and } 83.8 \% \text {. }\end{array}$ & Malaysia & [120] \\
\hline M. anisopliae & $\begin{array}{l}\text { Second and fourth instars on brinjals were sprayed } \\
\text { with } 2 \mathrm{~mL} \text { of } 10^{7}, 10^{5}, 10^{3} \text {, and } 10 \text { conidia/mL. }\end{array}$ & $\begin{array}{l}\mathrm{LC}_{50} \text { value: } \\
\text { Lowest on second instar, } 6.62 \times 10 \text { conidia } / \mathrm{mL} \text {. } \\
\mathrm{LT}_{50}: 2.25 \text { days }\end{array}$ & Malaysia & [118] \\
\hline M. anisopliae & $\begin{array}{l}\text { Second instars on eggplants were dipped into } 10^{8} \\
\text { conidia/mL for } 10 \mathrm{~s} .\end{array}$ & The highest mortality of $84.3 \%$ was observed in the isolate GT3. & Malaysia & [119] \\
\hline $\begin{array}{l}\text { B. bassiana, I. } \\
\text { fumosorosea, } \\
\quad \text { and } \\
\text { L. muscarium }\end{array}$ & $\begin{array}{l}\text { Nymphs were sprayed with conidia at } 10^{7} \\
\text { conidia/mL }\left(150 \text { conidia } / \mathrm{mm}^{2}\right)\end{array}$ & $\begin{array}{l}\text { All fungi isolates were pathogenic to whitefly nymphs. Isolates of } \\
\text { B. bassiana and I. fumosorosea were significantly more virulent than } \\
\text { that of } L \text {. muscarium, with }>77 \% \text { nymphal mortalities. }\end{array}$ & Brazil & [5] \\
\hline $\begin{array}{l}\text { B. bassiana, } M \text {. } \\
\text { anisopliae, } \\
\text { and I.fumosorosea }\end{array}$ & $\begin{array}{l}\text { Conidia at } 5 \times 10^{9} \text { conidia/ha were sprayed on } \\
\text { eggs; first, second, third, and fourth instars, } \\
\text { and adult } B \text {. tabaci on the underside of the leaves to } \\
\text { the point of runoff. }\end{array}$ & $\begin{array}{l}\text { There were no significant differences in individual mortality for } \\
\text { all life stages between the different strata (the top, middle, } \\
\text { and bottom thirds). M. anisopliae was significantly more effective } \\
\text { against eggs; first, second, and third instar nymphs; and pupae. }\end{array}$ & Mexico & [117] \\
\hline $\begin{array}{l}\text { B. bassiana } \\
\text { and L. lecanii }\end{array}$ & $\begin{array}{l}\text { Nymphs on tomato plants were sprayed with } \\
\text { fungal filtrate, conidia, and filtrate + conidia of } \\
\text { two fungal strains. }\end{array}$ & $\begin{array}{l}\text { In all the three bioassays, the isolate BB- } 72 \text { was the most virulent, } \\
\text { causing high mortality using all three different concentrations of } \\
\text { the two fungal strains tested. }\end{array}$ & China & [128] \\
\hline $\begin{array}{l}\text { M. anisopliae, } \\
\text { B. bassiana, } \\
\text { and V. lecanii }\end{array}$ & $\begin{array}{l}\text { Three different concentrations }\left(1 \times 10^{7}, 1 \times 10^{8}\right. \\
\left.\text { and } 1 \times 10^{9} \text { spores } / \mathrm{mL}\right) \text { were sprayed onto adult } B \text {. } \\
\text { tabaci. }\end{array}$ & $\begin{array}{l}\text { The percentage of reduction ranged between } 52 \% \text { and } 100 \% \text { in all } \\
\text { concentrations. All the treatments caused } 100 \% \text { mortality with } \\
\text { concentrations of } 1 \times 10^{9} \text { after the sixth day of application. }\end{array}$ & Egypt & [23] \\
\hline $\begin{array}{l}\text { M. anisopliae, } \\
\text { B. bassiana, } \\
\text { and V. lecanii }\end{array}$ & $\begin{array}{l}\text { Three different concentrations }\left(2 \times 10^{3}, 2 \times 10^{4},\right. \\
\text { and } 2 \times 10^{5} \text { conidia/mL) were sprayed onto adult } \\
\text { B. tabaci. }\end{array}$ & $\begin{array}{l}\text { The percentage of mortality ranged between } 80-100 \% \text { (V. lecanii), } \\
45-75 \% \text { (B. bassiana), and } 45-70 \%(M \text {. anisopliae) on the seventh } \\
\text { day after treatment. The concentration of } 2 \times 10^{5} \text { conidia/mL was } \\
\text { highly toxic under both laboratory and field conditions. }\end{array}$ & Egypt & [129] \\
\hline
\end{tabular}

Ref $=$ reference; $\mathrm{LC}_{50}=$ lethal concentration required to kill $50 \% ; \mathrm{LT}_{50}=$ lethal time required to kill $50 \%$. 


\section{The Infection Process and Life Cycle of Entomopathogenic Fungi on B. tabaci}

The insect cuticle is an important structure in the infection process of EPF as it is the main route for fungus penetration [89]. The steps involved in the infection process of EPF on B. tabaci are summarized in Figure 1. The fungus must first adhere to and interact with the epicuticular layer of the host by developing physical or enzymatic activities upon penetration into the insect cuticle $[89,130]$. However, some insects have a substance that can inhibit or promote conidia attachment or germination $[84,130]$. Attachment and germination of fungal spores start once they have landed on the insect cuticle. The pathogenic interaction of the EPF and the insect is established by the formation of an infective structure called the appressorium [131], which penetrates into the insect cuticle using mechanical pressure and cuticle-degrading enzymes [132]. The mechanical damage resulting from EPF penetration, toxicosis (toxins produced by the EPF), and nutrient exhaustion, leads to death of the insect $[75,133]$. The EPF grow sporadically within the insect hemocoel, and hyphae colonization of the cadaver following the death of insect.

The life cycle of EPF synchronizes with the insect life stages and environmental conditions [75,76]. Generally, the life cycle consists of a parasitic phase (from host infection to its death) and the saprophytic phase (after host death) [134]. The life cycle begins with the germination of spores following adhesion to the insect body [133]. The penetration of EPF into the insect body is a result of mechanical and physiological enzymatic activity of the germ tube [133]. Once the spores penetrate the insect body, yeast-like propagules are produced by budding-like growth and are distributed throughout the hemocoel [83]. Besides producing toxins, EPF can disrupt the metabolic processes of the insects through spores invading organs, thus resulting in the insect death [132]. Upon the insect death, the fungus colonizes the cadaver and reverts into the typical hyphal form (the saprophytic phase) due to sporulation $[83,134]$. The spores are then spread passively from the fungus-infected cadaver to new hosts [133].

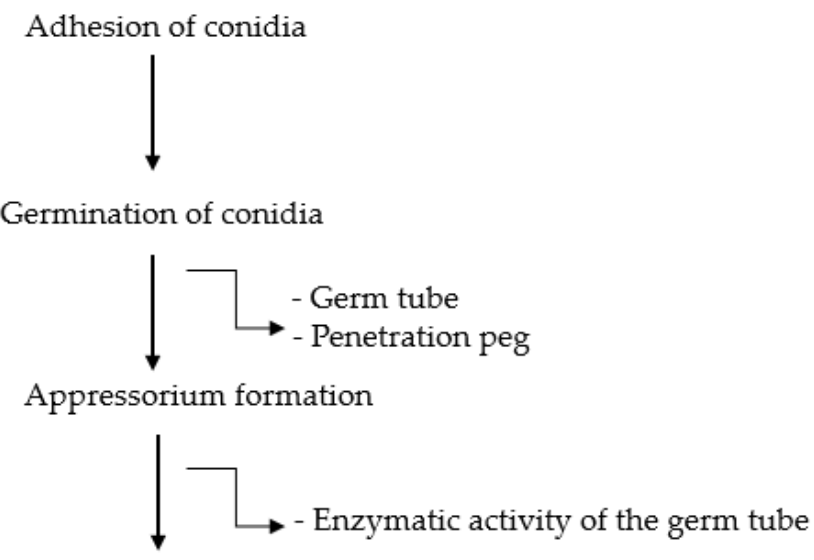

Penetration through the cuticle

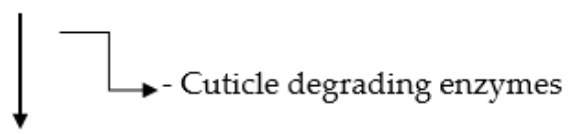

Colonization of the hemocoel

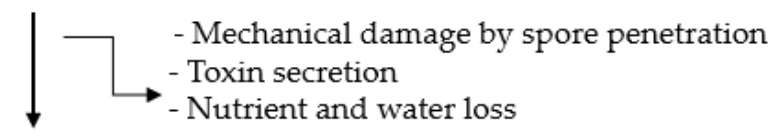

Death of insects

Figure 1. Diagrammatic representation of the EPF infection process on insects. 
In general, all EPF have the same mode of infection, including attachment of spores to the cuticle, germination of hyphae over the surface of insects, penetration of hyphae through the integument, growth of fungus in the hemocoel, and ultimately death of the whitefly (Figure 1) $[89,135]$.

\section{Merits and Demerits of Using EPF as Biological Control Measures}

The excessive use of chemical pesticides in agriculture has led to environmental contamination, as well as harmful effects on non-target organisms, including beneficial insects (pollinators), livestock, and humans. The application of EPF may, therefore, provide an alternative to the conventional use of chemical pesticides to effectively control insect pests, while preserving the natural environment, which is one of the main goals of sustainable agriculture [75].

The regulation of insect pests and arachnid populations has been significantly enhanced by the use of EPF, due to their major benefits over the use of chemical pesticides, including broad host range, the absence of harmful side effects for non-target organisms, easy mass production, low cost, and eco-friendliness [136-138]. Besides being efficient pest and disease control agents, EPF can also serve as plant growth promoters [132,137]. The unique infection mechanism of EPF ensures no issue of insect resistance, so they can be sustainably used as pest control [83]. Butt et al. [139] reported that compounds isolated from fungal biocontrol agents have led to the development of pharmaceutical drugs and safer agrochemicals.

Although EPF offer several advantages over chemical pesticides, there are some limitations to the application of EPF in controlling insect pests. One of the major limitations of EPF is the lengthy duration of 2-3 weeks to kill the insect pest population, whereas chemical pesticides may take only 2-3 h [83]. Environmental factors such as sunlight, temperature, humidity, and UV exposure can affect the insecticidal activity of EPF against insect pests in open fields of tropical regions [107]. The effectiveness of EPF in field trials with an uncontrolled environment may be hindered, although they can be successfully used in a controlled environment like a glasshouse [75]. Additionally, research related to the development of biocontrol agents or natural products has gained less popularity in terms of investment, in comparison to that concerning chemical pesticides [139].

\section{Conclusions}

Bemisia tabaci is considered a destructive insect pest of numerous crops around the world. Crops are affected directly by B. tabaci during feeding, and indirectly through the transmission of viral diseases, which can cause severe crop damage and yield losses worth millions of dollars. The control of $B$. tabaci relies heavily on pesticides despite several drawbacks, such as insecticide resistance and health risk to farmers and consumers. Hence, the IPM approach is deemed a safer and effective control measure to control B. tabaci, and includes the use of biological control, based exclusively on the effective use of natural parasites (parasitoids), predators, and entomopathogens.

The application of EPF as an effective biological control method of B. tabaci has been well demonstrated in various studies. The most common and popular EPF used to control B. tabaci are Ashersonia spp., B. bassiana, I. fumosoroseus, M. anisopliae, and Verticillium lecanii, each subject to various reviews. High populations of EPF and their effectiveness against $B$. tabaci can be sustained by improving conidia formulation and substrate. These efforts may increase the stability of EPF propagules and reduce the time required to kill B. tabaci. Moreover, some EPF, such as B. bassiana and M. anisopliae are associated with plants as symbiotic endophytes, which may help in the development of more effective insect pest management strategies. Endophytic inoculation of EPF in different parts of plants (foliar, root, seed, and stems) to effectively control B. tabaci could be utilized for the development of new IPM strategies. Taken together, EPF have a promising future in the sustainable control of B. tabaci.

Author Contributions: I.S. wrote the major part of the article. S.J., N.S., and J.J. constructed and made critical corrections in this paper. S.I.I. and S.A. provided supportive information on EPF and whitefly-transmitted viruses. All authors have read and agreed to the published version of the manuscript. 
Funding: This study was funded by the Fundamental Research Grant Scheme (FRGS) from the Ministry of Higher Education Malaysia (grant no. 5540212).

Acknowledgments: Authors would like to acknowledge the Universiti Putra Malaysia for the general support and provision of a conducive atmosphere for the study.

Conflicts of Interest: The authors declare no conflict of interest.

\section{References}

1. Perring, T.M.; Stansly, P.A.; Liu, T.X.; Smith, H.A.; Andreason, S.A. Whiteflies: Biology, ecology, and management. In Sustainable Management of Arthropod Pests of Tomato; Wakil, W., Brust, G.E., Perring, T.M., Eds.; Academic Press: Cambridge, MA, USA; Elsevier: Amsterdam, The Netherlands, 2018; pp. 73-110.

2. Alessandro, C.P.D.; Cuthbertson, A.G.S.; Lechner, B.E. Control of Bemisia tabaci by entomopathogenic fungi isolated from arid soils in Argentina. Biocontrol Sci. Technol. 2016, 26, 1668-1682.

3. Kunjwal, N.; Srivastava, R.M. Insect pests of vegetables. In Pests and Their Management; Springer Nature Singapore Pte Ltd.: Uttarakhand, India, 2018; pp. 163-221.

4. Khan, I.A.; Wan, F.H. Life history of Bemisia tabaci (Gennadius) (Homoptera: Aleyrodidae) biotype B on tomato and cotton host plants. J. Entomol. Zool. Stud. 2015, 3, 117-121.

5. Mascarin, G.M.; Kobori, N.N.; Quintela, E.D.; Delalibera, I. The virulence of entomopathogenic fungi against Bemisia tabaci biotype B (Hemiptera: Aleyrodidae) and their conidial production using solid substrate fermentation. Biol. Control 2013, 66, 209-218. [CrossRef]

6. Eslamizadeh, R.; Sajap, A.S.B.; Omar, D.B.; Azura, N.; Adam, B. Evaluation of different isolates of the entomopathogenic fungus, Paecilomyces fumosoroseus (Deuteromycotina: Hyphomycetes) against Bemisia tabaci (Hemiptera: Aleyrodidae). Biol. Control Plant Prot. 2015, 2, 82-90.

7. Hasan, I.; Rasul, S.; Malik, T.H.; Qureshi, M.K.; Aslam, K.; Shabir, G.; Athar, H.; Manzoor, H. Present status of cotton leaf curl virus disease (CLCUVD): A major threat to cotton production. Int. J. Cott. Res. Technol. 2019, 1, 1-13.

8. Choudhary, H.; Parihar, S.; Singh, S.; Parvez, N. Technical Bulletin on Whiteflies; Choudhary, H., Parihar, S., Singh, S., Parvez, N., Eds.; National Innovation Foundation-India: Gujarat, India, 2017.

9. Polston, J.E.; Capobianco, H. Transmitting plant viruses using whiteflies. J. Vis. Exp. 2013, 81, 1-10. [CrossRef]

10. Kumarasinghe, N.; Salim, N.; Wijayarathne, W. Identification and biology of two whitefly species on cassava in Sri Lanka. J. Plant Prot. Res. 2009, 49, 373-377. [CrossRef]

11. Stansly, P.A.; Natwick, E.T. Integrated systems for managing Bemisia tabaci in protected and open field agriculture. In Bemisia: Bionomics and Management of a Global Pest; Springer Science+Business Media, B.V.: Dordrecht, The Netherlands, 2009; pp. 467-497.

12. Gao, T.; Wang, Z.; Huang, Y.; Keyhani, N.O.; Huang, Z. Lack of resistance development in Bemisia tabaci to Isaria fumosorosea after multiple generations of selection. Sci. Rep. 2017, 7, 1-11. [CrossRef]

13. Cuthbertson, A.G.S. Update on the status of Bemisia tabaci in the UK and the use of entomopathogenic fungi within eradication programmes. Insects 2013, 4, 198-205. [CrossRef]

14. Smith, H.A.; Stansly, P.A.; Seal, D.R.; Mcavoy, E.; Polston, J.E.; Phyllis, R.; Schuster, D.J. Management of Whiteflies, Whitefly-Vectored Plant Virus, and Insecticide Resistance for Tomato Production; ENY-735; University of Florida, IFAS, Florida A\&M University and Cooperative Extension Program: Gainesville, FL, USA, 2018; pp. 1-8.

15. Skinner, M.; Parker, B.L.; Kim, J.S. Role of entomopathogenic fungi in integrated pest management. In Integrated Pest Management: Current Concepts and Ecological Perspective; Elsevier Inc.: Amsterdam, The Netherlands, 2013; pp. 109-191.

16. Smith, H.A.; Krey, K.L. Three release rates of Dicyphus hesperus (Hemiptera: Miridae) for management of Bemisia tabaci (Hemiptera: Aleyrodidae) on greenhouse tomato. Insects 2019, 10, 213. [CrossRef]

17. Jiang, W.; Peng, Y.; Ye, J.; Wen, Y.; Liu, G.; Xie, J. Effects of the entomopathogenic fungus Metarhizium anisopliae on the mortality and immune response of Locusta migratoria. Insects 2020, 11, 36. [CrossRef] [PubMed]

18. Bugti, G.A.; Bin, W.; Na, C.; Feng, L.H. Pathogenicity of Beauveria bassiana strain 202 against sap-sucking insect pests. Plant Prot. Sci. 2018, 54, 111-117. 
19. Rios-Velasco, C.; Pérez-Corral, D.A.; Salas-Marina, M.Á.; Berlanga-Reyes, D.I.; Ornelas-Paz, J.J.; Muñiz, C.H.A.; Cambero-Campos, J.; Jacobo-Cuellar, J.L. Pathogenicity of the hypocreales fungi Beauveria bassiana and Metarhizium anisopliae against insect pests of tomato. Southwest. Entomol. 2014, 39, 739-750. [CrossRef]

20. Sain, S.K.; Monga, D.; Kumar, R.; Nagrale, D.T.; Kranthi, S.; Kranthi, K.R. Comparative effectiveness of bioassay methods in identifying the most virulent entomopathogenic fungal strains to control Bemisia tabaci (Gennadius) (Hemiptera: Aleyrodidae). Egypt. J. Biol. Pest Control 2019, 29, 1-11. [CrossRef]

21. Panyasiri, C.; Attathom, T.; Poehling, H.M. Pathogenicity of entomopathogenic fungi-potential candidates to control insect pests on tomato under protected cultivation in Thailand. J. Plant Dis. Prot. 2007, 114, 278-287. [CrossRef]

22. Borisade, O.A. Rearing tomato whitefly and field evaluation of modified and unmodified conidia of Beauveria bassiana, Isaria farinosa, Metarhizium anisopliae and low rates of chlorpyrifos under tropical conditions. Afr. Crops Sci. J. 2015, 23, 177-195.

23. Abdel-Raheem, M.A.; Lamya, A.A.-K. Virulence of three entomopathogenic fungi against whitefly, Bemisia tabaci (Gennadius) (Hemiptera: Aleyrodidae) in tomato crop. J. Entomol. 2016, 14, 155-159.

24. Zhang, C.; Ali, S.; Musa, P.D.; Wang, X.M.; Qiu, B.L. Evaluation of the pathogenicity of Aschersonia aleyrodis on Bemisia tabaci in the laboratory and greenhouse. Biocontrol Sci. Technol. 2017, 27, 210-221. [CrossRef]

25. del Prado, E.N.; Iannacone, J.; Gómez, H. Effect of two entomopathogenic fungi in controlling Aleurodicus cocois (Curtis, 1846) (Hemiptera: Aleyrodidae). Chil. J. Agric. Res. 2008, 68, 21-30. [CrossRef]

26. Kanakala, S.; Ghanim, M. Global genetic diversity and geographical distribution of Bemisia tabaci and its bacterial endosymbionts. PLOS ONE 2019, 14, e0213946. [CrossRef]

27. Gangwar, R.K.; Charu, G. Lifecycle, distribution, nature of damage and economic importance of whitefly, Bemisia tabaci (Gennadius). Acta Sci. Agric. 2018, 2, 36-39.

28. Hodges, G.S.; Evans, G.A. An Identification guide to the whiteflies (Hemiptera: Aleyrodidae) of the Southeastern United States. Fla. Entomol. 2005, 88, 518-534.

29. Baig, M.M.; Dubey, A.K.; Ramamurthy, V.V. Determination of sexual dimorphism in the puparia of four whitefly pest species from India (Hemiptera: Aleyrodidae). Acta Entomol. Musei Natl. Pragae 2016, 56, 447-460.

30. Boykin, L.M.; Bell, C.D.; Evans, G.; Small, I.; De Barro, P.J. Is agriculture driving the diversification of the Bemisia tabaci species complex (Hemiptera: Sternorrhyncha: Aleyrodidae)?: Dating, diversification and biogeographic evidence revealed. BMC Evol. Biol. 2013, 13, 1-10. [CrossRef] [PubMed]

31. Liu, T.-X.; Stansly, P.A.; Gerling, D. Whitefly Parasitoids: Distribution, life history, bionomics, and utilization. Annu. Rev. Entomol. 2015, 60, 273-292. [CrossRef] [PubMed]

32. de Moraes, L.A.; Muller, C.; de Bueno, R.C.O.F.; Santos, A.; Bello, V.H.; De Marchi, B.R.; Watanabe, L.F.M.; Marubayashi, J.M.; Santos, B.R.; Yuki, V.A.; et al. Distribution and phylogenetics of whiteflies and their endosymbiont relationships after the Mediterranean species invasion in Brazil. Sci. Rep. 2018, 8, 1-13. [CrossRef] [PubMed]

33. Marubayashi, J.M.; Yuki, V.A.; Rocha, K.C.G.; Mituti, T.; Pelegrinotti, F.M.; Ferreira, F.Z.; Moura, M.F.; Navas-Castillo, J.; Moriones, E.; Pavan, M.A.; et al. At least two indigenous species of the Bemisia tabaci complex are present in Brazil. J. Appl. Entomol. 2013, 137, 113-121. [CrossRef]

34. De Marchi, B.R.; Kinene, T.; Mbora Wainaina, J.; Krause-Sakate, R.; Boykin, L. Comparative transcriptome analysis reveals genetic diversity in the endosymbiont hamiltonella between native and exotic populations of Bemisia tabaci from Brazil. PLoS ONE 2018, 13, e0201411.

35. Shadmany, M.; Boykin, L.M.; Muhamad, R.; Omar, D. Genetic diversity of Bemisia tabaci (Hemiptera: Aleyrodidae) species complex across Malaysia. J. Econ. Entomol. 2019, 112, 75-84. [CrossRef]

36. Curnutte, L.B.; Simmons, A.M.; Abd-Rabou, S. Climate change and Bemisia tabaci (Hemiptera: Aleyrodidae): Impacts of temperature and carbon dioxide on life history. Ann. Entomol. Soc. Am. 2014, 107, 933-943. [CrossRef]

37. Li, N.; Li, Y.; Zhang, S.; Fan, Y.; Liu, T. Effect of elevated $\mathrm{CO}_{2}$ concentration and temperature on antioxidant capabilities of multiple generations of Bemisia tabaci MEAM1 (Hemiptera: Aleyrodidae). J. Insect Physiol. 2017, 103, 91-97. [CrossRef] [PubMed]

38. Fekrat, L.; Shishehbor, P. Some biological features of cotton whitefly, Bemisia tabaci (Homoptera: Aleyrodidae) on various host plants. Pak. J. Biol. Sci. 2007, 10, 3180-3184. [PubMed] 
39. Solanki, R.D.; Jha, S. Population dynamics and biology of whitefly (Bemisia tabaci Gennadius) on sunflower (Helianthus annuus L.). J. Pharmacogn. Phytochem. 2018, 7, 3055-3058.

40. Smith, P.E. Crop and Food Research. In Whitefly: Identification and Biology in New Zealand Greenhouse Tomato Crops; Smith, P.E., Ed.; AsureQuality Ltd.: Auckland, New Zealand, 2009; pp. 1-8.

41. Kedar, S.C.; Saini, R.K.; Kumaranag, K.M. Biology of cotton whitefly, Bemisia tabaci (Hemiptera: Aleyrodidae) on cotton. J. Entomol. Res. 2014, 38, 135-139.

42. Naranjo, S.E.; Frei, G. Chapter 6 Biology, ecology, and management of sweetpotato whiteflies on cotton. In Sticky Cotton: Causes, Effects, and Prevention; Hequet, E., Ed.; USAD: Orange County, CA, USA, 2007; pp. 51-67.

43. Lindquist, R.K.; Cloyd, R.A. Identification of Insects and Related Pests of Horticultural Plants; Cuthbert, C., Carver, S.C., Eds.; O.F.A. Services, Inc.: Columbus, OH, USA, 2005; pp. 1-50.

44. Samih, M.A.; Zarabi, M.; Yazdani, M.; Rouhani, M. Biological traits and life table parameters A and B biotype of Bemisia tabaci (Genn.) on cotton and rapeseed. Braz. Arch. Biol. Technol. 2014, 57, 309-316. [CrossRef]

45. Ou, D.; Ren, L.M.; Liu, Y.; Ali, S.; Wang, X.M.; Ahmed, M.Z.; Qiu, B.L. Compatibility and efficacy of the parasitoid Eretmocerus hayati and the entomopathogenic fungus Cordyceps javanica for biological control of whitefly Bemisia tabaci. Insects 2019, 10, 425. [CrossRef] [PubMed]

46. Jones, D.R. Plant viruses transmitted by whiteflies. Eur. J. Plant Pathol. 2003, 109, 195-219. [CrossRef]

47. Götz, M.; Winter, S. Diversity of Bemisia tabaci in Thailand and Vietnam and indications of species replacement. J. Asia. Pac. Entomol. 2016, 19, 537-543. [CrossRef]

48. Lu, S.; Chen, M.; Li, J.; Shi, Y.; Gu, Q.; Yan, F. Changes in Bemisia tabaci feeding behaviors caused directly and indirectly by cucurbit chlorotic yellows virus. Virol. J. 2019, 16, 1-14. [CrossRef]

49. Legg, J.P.; Shirima, R.; Tajebe, L.S.; Guastella, D.; Boniface, S.; Jeremiah, S.; Nsami, E.; Chikoti, P.; Rapisarda, C. Biology and management of Bemisia whitefly vectors of cassava virus pandemics in Africa. Pest Manag. Sci. 2014, 70, 1446-1453. [CrossRef]

50. Iqbal, M.; State, K.; Academy, M.; Naeem, M.; Aziz, U.; Khan, M. An overview of cotton leaf curl virus disease, persistent challenge for cotton production an overview of cotton leaf curl virus disease, persistent challenge for cotton production. Bulg. J. Agric. Sci. 2014, 20, 405-415.

51. Liu, B.; Preisser, E.L.; Chu, D.; Pan, H.; Xie, W.; Wang, S.; Wu, Q.; Zhou, X. Multiple forms of vector manipulation by a plant-infecting virus: Bemisia tabaci and tomato yellow leaf curl virus. J. Virol. 2013, 87, 4929-4937. [CrossRef] [PubMed]

52. Dutta, B.; Myers, B.; Coolong, T.; Srinivasan, B.; Sparks, A.; Riley, D. Whitefly-transmitted plant viruses in South Georgia. UGA Coop. Ext. Bull. 2018, 1507, 1-7.

53. Fiallo-Olivé, E.; Pan, L.L.; Liu, S.S.; Navas-Castillo, J. Transmission of begomoviruses and other whitefly-borne viruses: Dependence on the vector species. Phytopathology 2020, 110, 10-17. [CrossRef] [PubMed]

54. Ning, W.; Shi, X.; Liu, B.; Pan, H.; Wei, W.; Zeng, Y.; Sun, X.; Xie, W.; Wang, S.; Wu, Q.; et al. Transmission of tomato yellow leaf curl virus by Bemisia tabaci as affected by whitefly sex and biotype open. Sci. Rep. 2015, 5, 10744. [CrossRef] [PubMed]

55. Navas-Castillo, J.; Fiallo-Olivé, E.; Sánchez-Campos, S. Emerging virus diseases transmitted by whiteflies. Annu. Rev. Phytopathol. 2011, 49, 219-248. [CrossRef]

56. Czosnek, H.; Hariton-Shalev, A.; Sobol, I.; Gorovits, R.; Ghanim, M. The incredible journey of Begomoviruses in their whitefly vector. Viruses 2017, 9, 273. [CrossRef]

57. Horowitz, A.R.; Antignus, Y.; Gerling, D. Management of Bemisia tabaci whiteflies. In The Whitefly, Bemisia Tabaci (Homoptera: Aleyrodidae) Interaction with Geminivirus-Infected Host Plants; Thompson, W.M.O., Ed.; Springer: Dordrecht, The Netherlands, 2011; pp. 293-322.

58. Firdaus, S.; van Heusden, A.W.; Hidayati, N.; Supena, E.D.J.; Visser, R.G.F.; Vosman, B. Resistance to Bemisia tabaci in tomato wild relatives. Euphytica 2012, 187, 31-45. [CrossRef]

59. Syed, T.S.; Abro, G.H.; Khuhro, R.D.; Dhauroo, M.H. Relative resistance of cotton varieties against sucking pests. Pak. J. Biol. Sci. 2003, 6, 1232-1233.

60. Ullah, F.; Baloch, A.F.; Badshah, H. Studies of varietal resistance and chemical control against whiteflies in cotton. J. Biol. Sci. 2006, 6, 261-264. [CrossRef] 
61. Silva, K.F.A.S.; Michereff-Filho, M.; Fonseca, M.E.N.; Silva-Filho, J.G.; Texeira, A.C.A.; Moita, A.W.; Torres, J.B.; Fernández-Muñoz, R.; Boiteux, L.S. Resistance to Bemisia tabaci biotype B of Solanum pimpinellifolium is associated with higher densities of type IV Glandular trichomes and acylsugar accumulation. Entomol. Exp. Appl. 2014, 151, 218-230. [CrossRef]

62. Bugti, G.A. Varietal preference of insect pests on tomato crop in district Naseerabad Balochistan Pakistan. J. Entomol. Zool. Stud. JEZS 2016, 4, 328-330.

63. Hamid, M.N.; Noor, M.R.; Piang, L. Non pesticide methods for controlling diseases and insect. In APO Seminar on Non Pesticide Methods for Controlling Diseases and Insect Pests; Ooi, P.A.C., Ed.; Asian Productivity Organization: Tokyo, Japan, 2002; pp. 100-111.

64. Takikawa, Y.; Matsuda, Y.; Kakutani, K.; Nonomura, T.; Kusakari, S.I.; Okada, K.; Kimbara, J.; Osamura, K.; Toyoda, H. Electrostatic insect sweeper for eliminating whiteflies colonizing host plants: A complimentary pest control device in an electric field screen-guarded greenhouse. Insects 2015, 6, 442-454. [CrossRef] [PubMed]

65. Parrella, M.P.; Hanse, L.S.; van Lenteren, J.C. Glasshouse Environments. In Handbook of Biological Control; Academic Press: Cambridge, MA, USA, 1999; pp. 819-839.

66. Halimatunsadiah, A.B.; Norida, M.; Omar, D.; Kamarulzaman, N.H. Application of pesticide in pest management: The case of lowland vegetable growers. Int. Food Res. J. 2016, 23, 85-94.

67. Palumbo, J.C.; Horowitz, A.R.; Prabhaker, N. Insecticidal control and resistance management for Bemisia Tabaci. Crop Prot. 2001, 20, 739-765. [CrossRef]

68. Naveen, N.C.; Chaubey, R.; Kumar, D.; Rebijith, K.B.; Rajagopal, R.; Subrahmanyam, B.; Subramanian, S. Insecticide resistance status in the whitefly, Bemisia tabaci genetic groups Asia-I, Asia-II-1 and Asia-II-7 on the Indian subcontinent. Sci. Rep. 2017, 7, 1-15. [CrossRef]

69. Avery, P.B.; Kumar, V.; Skvarch, E.A.; Mannion, C.M.; Powell, C.A.; Mckenzie, C.L.; Osborne, L.S. An ecological assessment of Isaria fumosorosea applications compared to a neonicotinoid treatment for regulating invasive ficus whitefly. J. Fungi 2019, 5, 36. [CrossRef]

70. Shinde, B.D.; Mokal, A.J.; Narangalkar, A.; Naik, K.V. Chemical management of whiteflies infesting chili. Int. J. Chem. Stud. 2018, 6, 2813-2816.

71. Xu, D.; Ali, S.; Huang, Z.; Zhou, F.C.; Afzal, M.; Bashir, M.H. Influence of the entomopathogenic fungus, Verticillium lecanii on the whitefly predator, Axinoscymnus cardilobus (Coleoptera: Coccinellidae) Under Laboratory Conditions. Pak. J. Zool. 2009, 41, 289-295.

72. Colmenarez, Y.; Jahnke, S.M.; Sampaio, M.V. Use of parasitoids as a biocontrol agent in the Neotropical region: Challenges and potential. In Hymenopteran Wasps-The Parasitoids; Intechopen: London, UK, 2018; pp. 1-25.

73. Rodríguez, E.; Téllez, M.; Janssen, D. Whitefly Control strategies against tomato leaf curl New Delhi virus in greenhouse zucchini. Int. J. Environ. Res. Public Health 2019, 16, 2673. [CrossRef]

74. Bale, J.S.; Van Lenteren, J.C.; Bigler, F. Biological control and sustainable food production. Philos. Trans. R. Soc. B Biol. Sci. 2008, 363, 761-776. [CrossRef] [PubMed]

75. Singh, D.; Raina, T.K.; Singh, J. Entomopathogenic fungi: An effective biocontrol agent for management of insect populations naturally. J. Pharm. Sci. Res. 2017, 9, 830-839.

76. Shahid, A.A.L.I.; Rao, A.Q.; Bakhsh, A.; Husnain, T. Entomopathogenic fungi as biological controllers: New insights into their virulence and pathogenicity. Arch. Biol. Sci. Belgrade 2012, 64, 21-42. [CrossRef]

77. Lahey, A.; Lahey, Z.; Stansly, P. An updated list of parasitoid Hymenoptera reared from the Bemisia tabaci species complex (Hemiptera: Aleyrodidae). Fla. Entomol. 2020, 98, 456-463. [CrossRef]

78. Shah, M.M.R.; Zhang, S.; Liu, T. Whitefly, Host plant and parasitoid: A Review on their whitefly, host plant and parasitoid: A review on their interactions. Asian J. Appl. Sci. Eng. 2015, 4, 48-61.

79. Xu, H.; Yang, N.; Wan, F. Competitive interactions between parasitoids provide new insight into host suppression. PLoS ONE 2013, 8, e82003. [CrossRef]

80. Kidane, D.; Yang, N.; Wan, F. Evaluation of a banker plant system for biological control of Bemisia tabaci (Hemiptera: Aleyrodidae) on tomato, using two aphelinid parasitoids under field-cage conditions. Biocontrol Sci. Technol. 2018, 28, 1054-1073. [CrossRef]

81. Kedar, S.C.; Saini, R.K.; Kumaranag, K.M.; Sharma, S.S. Record of natural enemies of whitefly, Bemisia tabaci (Gennadius) (Hemiptera: Aleyrodidae) in some cultivated crops in Haryana. J. Biopestic. 2014, 7, 57-59. 
82. Nomikou, M.; Janssen, A.; Sabelis, M.W. Phytoseiid predators of whiteflies feed and reproduce on non-prey food sources. Exp. Appl. Acarol. 2003, 31, 15-26. [CrossRef]

83. Khan, S.; Guo, L.; Maimaiti, Y.; Mijit, M.; Qiu, D. Entomopathogenic fungi as microbial biocontrol agent. Mol. Plant Breed. 2012, 3, 63-79. [CrossRef]

84. Abdelghany, T.M. Entomopathogenic Fungi and Their Role in Biological Control; El-Ghany, T.M.A., Ed.; OMICS Group eBooks: Foster City, CA, USA, 2015; pp. 1-42.

85. Ibrahim, A.A.; Mohamed, H.F.; El-Naggar, S.E.M.; Swelim, M.A.; Elkhawaga, O.E. Isolation and selection of entomopathogenic fungi as biocontrol agent against the greater wax moth, Galleria mellonella 1. (Lepidoptera: Pyralidae). Egypt. J. Biol. Pest Control 2016, 26, 249-253.

86. Uztan, A.H.; Gunyar, O.A.; Yoltas, A.; Keskin, N. Isolation and identification of entomopathogenic fungi Beauveria bassiana from Turkey. Fresenius Environ. Bull. 2016, 25, 5180-5185.

87. Ravensberg, W.J. A Roadmap to the Successful Development and Commercialization of Microbial Pest Control Products for Control of Arthropods; Progress in Biological Control Series; Springer Science+Business Media, B.V.: Dordrecht, The Netherlands, 2011; pp. 59-127.

88. Mora, M.A.E.; Rouws, J.R.C.; Fraga, M.E. Occurrence of entomopathogenic fungi in Atlantic forest soils. Microbiol. Discov. 2016, 4, 1. [CrossRef]

89. Tahira, H.G.; Saeed, S.; Khan, F.Z.A. Entomopathogenic fungi as effective insect pest management tactic: A Review. Appl. Sci. Bus. Econ. 2014, 1, 10-18.

90. Anwar, W.; Ali, S.; Nawaz, K.; Iftikhar, S.; Javed, M.A.; Hashem, A.; Alqarawi, A.A.; Abd Allah, E.F.; Akhter, A. Entomopathogenic fungus Clonostachys rosea as a biocontrol agent against whitefly (Bemisia tabaci). Biocontrol Sci. Technol. 2018, 28, 750-760. [CrossRef]

91. Wang, P.; Song, X.; Zhang, H. Isolation and characterization of Aschersonia placenta from citrus orchards and its pathogenicity towards Dialeurodes citri (Ashmead). J. Invertebr. Pathol. 2013, 112, 122-128. [CrossRef] [PubMed]

92. Liu, M.; Chaverri, P.; Hodge, K.T. A taxonomic revision of the insect biocontrol fungus Aschersonia aleyrodis, its allies with white stromata and their Hypocrella sexual states. Mycol. Res. 2006, 110, 537-554. [CrossRef]

93. Zhang, C.; Shao, Z.F.; Han, Y.Y.; Wang, X.M.; Wang, Z.Q.; Musa, P.D.; Qiu, B.L.; Ali, S. Effects of Aschersonia aleyrodis on the life table and demographic parameters of Bemisia Tabaci. J. Integr. Agric. 2018, 17, 389-396. [CrossRef]

94. Prayogo, Y.; Bayu, M.S.Y.I. Biological control of Bemisia tabaci gennadius by using entomopathogenic fungi Aschersonia aleyrodis. In IOP Conference Series: Earth and Environmental Science; IOP Publishing Ltd.: Bristol, UK, 2020; Volume 456, pp. 1-8.

95. Al-Deghari, M.A. Bioassay Evaluation of the entomopathogenic fungi, Beauveria bassiana Vuellemin against eggs and nymphs of Bemisia tabaci Gennadius (Homoptera: Aleyrodidae). Pak. J. Biol. Sci. 2008, 11, 1551-1560. [CrossRef]

96. Zafar, J.; Freed, S.; Khan, B.A.; Farooq, M. Effectiveness of Beauveria bassiana against cotton whitefly, Bemisia tabaci (Gennadius) (Aleyrodidae: Homoptera) on different host plants. Pak. J. Zool. 2016, 48, 91-99.

97. Prithiva, J.N.; Ganapathy, N.; Jeyarani, S. Efficacy of different formulations of Beauveria bassiana (Bb 112) against Bemisia tabaci on tomato. J. Entomol. Zool. Stud. 2017, 5, 1239-1243.

98. Arcía, G.T.O.; Eña, A.H.U.E.L.A.P.; Daniel, L.; Artínez, O.R.; Antonio, J.; Agallón, S.A. Interaction of Beauveria bassiana strain HPI-019/14 and Bacillus thuringiensis strain GP139 for the biological control of Bemisia tabaci in strawberry. Bull. Insectol. 2018, 71, 201-209.

99. Nascimento Silva, J.; Mascarin, G.M.; Paula Vieira de Castro, R.; Castilho, L.R.; Freire, D.M. Novel combination of a biosurfactant with entomopathogenic fungi enhance efficacy against Bemisia whitefly. Pest Manag. Sci. 2019, 75, 2882-2891. [CrossRef] [PubMed]

100. Islam, M.T.; Omar, D.; Latif, M.A.; Morshed, M.M. The integrated use of entomopathogenic fungus, Beauveria bassiana with botanical insecticide, neem against Bemisia tabaci on eggplant. Afr. J. Microbiol. Res. 2011, 5, 3409-3413.

101. Jaber, L.R.; Araj, S.E.; Qasem, J.R. Compatibility of endophytic fungal entomopathogens with plant extracts for the management of sweetpotato whitefly Bemesia tabaci Gennadius (Homoptera: Aleyrodidae). Biol. Control 2018, 117, 164-171. [CrossRef]

102. Islam, M.T.; Castle, S.J.; Ren, S. Compatibility of the insect pathogenic fungus Beauveria bassiana with neem against sweetpotato whitefly, Bemisia tabaci, on eggplant. Entomol. Exp. Appl. 2010, 134, 28-34. [CrossRef] 
103. Cuthbertson, A.G.S.; Collins, D.A. Tri-Tek (Petroleum Horticultural Oil) and Beauveria bassiana: Use in eradication strategies for Bemisia tabaci Mediterranean species in UK glasshouses. Insects 2015, 6, 133-140. [CrossRef]

104. Huang, Z.; Ali, S.; Ren, S.; Wu, J. Effect of Isaria fumosoroseus on mortality and fecundity of Bemisia tabaci and Plutella xylostella. Insect Sci. 2010, 17, 140-148. [CrossRef]

105. Kereselidze, M.; Draganova, S.; Pilarska, D.; Linde, A. Susceptibility of Lymantria monacha and L. dispar to the entomopathogenic fungus Isaria fumosorosea wize. Sumar. List 2014, 138, 185-191.

106. Mascarin, G.M.; Alves, S.B.; Lopes, R.B. Culture media selection for mass production of Isaria fumosorosea and Isaria farinosa. Braz. Arch. Biol. Technol. 2010, 53, 753-761. [CrossRef]

107. Loong, C.; Ahmad, S.S.; Hafidzi, M.N.; Dzolkifli, O.; Faizah, A. Effect of UV-B and solar radiation on the efficacy of Isaria fumosorosea and Metarhizium anisopliae (Deuteromycetes: Hyphomycetes) for controlling bagworm, Pterona pendula (Lepidoptera: Psychidae). J. Entomol. 2013, 10, 53-65.

108. Rahim, E.; Ahmad, S.S.; Dzolkhifli, O.; Nur, A.A. First record of Isaria fumosorosea Wize (Deuteromycotina: Hyphomycetes) infecting Bemisia tabaci (Gennadius) (Hemiptera: Aleyrodidae) in Malaysia. J. Entomol. 2013, 10, 182-190.

109. Zou, C.; Li, L.; Dong, T.; Zhang, B.; Hu, Q. Joint action of the entomopathogenic fungus Isaria fumosorosea and four chemical insecticides against the whitefly Bemisia tabaci. Biocontrol Sci. Technol. 2014, 24, 315-324. [CrossRef]

110. Cuthbertson, A.G.S.; Walters, K.F.A. Pathogenicity of the entomopathogenic fungus, Lecanicillium muscarium, against the sweetpotato whitefly Bemisia tabaci under laboratory and glasshouse conditions. Mycopathologia 2005, 160, 315-319. [CrossRef] [PubMed]

111. Espinosa, D.J.L.; da Silva, I.H.S.; Duarte, R.T.; Goncalves, K.C.; Polanczyk, R.A. Potential of entomopathogenic fungi as biological control agents of whitefly (Bemisia tabaci biotype B) (Genn.) (Hemiptera: Aleyrodidae). J. Exp. Agric. Int. 2019, 38, 1-8. [CrossRef]

112. Cuthbertson, A.G.S.; Walters, K.F.A.; Deppe, C. Compatibility of the entomopathogenic fungus Lecanicillium muscarium and insecticides for eradication of sweetpotato whitefly, Bemisia Tabaci. Mycopathologia 2005, 160, 35-41. [CrossRef]

113. Cuthbertson, A.G.S.; Blackburn, L.F.; Northing, P.; Weiqi, L.; Cannon, R.J.C.; Walters, K.F.A. Further compatibility tests of the entomopathogenic fungus Lecanicillium muscarium with conventional insecticide products for control of sweetpotato whitefly, Bemisia tabaci on poinsettia plants. Insect Sci. 2008, 15, 355-360. [CrossRef]

114. Cuthbertson, A.G.S.; Blackburn, L.F.; Northing, P.; Luo, W.; Cannon, R.J.C.; Walters, K.F.A. Chemical compatibility of the entomopathogenic fungus Lecanicillium muscarium to control Bemisia tabaci in glasshouse environment. Int. J. Environ. Sci. Technol. 2010, 7, 405-409. [CrossRef]

115. Malsam, O.; Kilian, M.; Dehne, H.W. Metarhizium anisopliae biological control of the greenhouse whitefly (Trialeurodes vaporariorum). IOBC-WPRS Bull. 1998, 21, 125-128.

116. Meekes, E.T.M. Entomopathogenic Fungi against Whiteflies: Trophic Interactions between Aschersonia Species, Trialeurodes Vaporariorum and Bemisia Argentifolii, and Glasshouse Crops; Wageningen University: Wageningen, The Netherlands, 2001.

117. Flores, M.; Pucheta, D.; Rodriguez, N.; Torre, M.; Ramos, L. Mycoinsecticide effects of Beauveria bassiana, Metarhizium anisopliae, and Isaria fumosorosea on the whitefly Bemisia tabaci (Homoptera: Aleyrodidae) in different strata of bean. Afr. J. Microbiol. Res. 2012, 6, 7246-7252.

118. Norhelina, L.; Sajap, A.S.; Mansour, S.A.; Idris, A.B. Infectivity of five Metarhizium anisopliae (Deuteromycota: Hyphomycetales) strains on whitefly, Bemisia tabaci (homoptera: Aleyrodidae) infesting brinjal, Solanum Melongena. Acad. J. Entomol. 2013, 6, 127-132.

119. Islam, M.T.; Omar, D.; Shabanimofrad, M. Molecular identification and virulence of six isolates of Metarhizium anisopliae (Deuteromycotina: Hyphomycetes) to Bemisia tabaci Q biotype. J. Asia. Pac. Entomol. 2014, 17, 237-241. [CrossRef]

120. Islam, M.T.; Omar, D.; Shah, A.K.M.A.; Hasan, M.F. Virulence of entomopathogenic fungus, Metarhizium anisopliae to Sweetpotato whitefly, Bemisia tabaci (Hemiptera: Aleyrodidae) under osmotic stress. Proc. Natl. Acad. Sci. India Sect. B-Biol. Sci. 2016, 86, 617-622. [CrossRef]

121. Qiu, J.; Song, F.; Mao, L.; Tu, J.; Guan, X. Time-dose-mortality data and modeling for the entomopathogenic fungus. Can. J. Microbiol. 2013, 101, 97-101. [CrossRef] [PubMed] 
122. Maranha, E.A.; Maranha, E. Host plant influences pathogenicity of Beauveria bassiana to Bemisia tabaci and its sporulation on cadavers. BioControl 2006, 51, 519-532.

123. Imam, I.I. Role of certain Beauveria bassiana isolate as biological control agent against whitefly, Bemisia tabaci (Genn.) and its effect on the predator Chrysopela carnea (stephens). Egypt. J. Desert Res. 2017, 67, 351-359. [CrossRef]

124. Cabanillas, H.E.; Jones, W.A. Pathogenicity of Isaria sp. (Hypocreales: Clavicipitaceae) against the sweet potato whitefly B biotype, Bemisia tabaci (Hemiptera: Aleyrodidae). Crop Prot. 2009, 28, 333-337. [CrossRef]

125. Tian, J.; Diao, H.; Liang, L.; Arthurs, S.; Ma, R. Pathogenicity of Isaria fumosorosea to Bemisia tabaci, with some observations on the fungal infection process and host immune response. J. Invertebr. Pathol. 2015, 130, 147-153. [CrossRef]

126. Wang, L.; Huang, J.; You, M.; Guan, X.; Liu, B. Toxicity and feeding deterrence of crude toxin extracts of Lecanicillium (Verticillium) Lecanii (Hyphomycetes) against sweetpotato whitefly, Bemisia tabaci (Homoptera: Aleyrodidae). Pest Manag. Sci. 2007, 63, 381-387. [CrossRef]

127. Cuthbertson, A.G.S.; Walters, K.F.A.; Northing, P. The susceptibility of immature stages of Bemisia tabaci to the entomopathogenic fungus Lecanicillium muscarium on tomato and verbena foliage. Mycopathologia 2005, 159, 23-29. [CrossRef]

128. Keerio, A.U.; Nazir, T.; Abdulle, Y.A.; Jatoi, G.H.; Gadhi, M.A.; Anwar, T.; Sokea, T.; Qiu, D. In vitro pathogenicity of the fungi Beauveria bassiana and Lecanicillium lecanii at different temperatures against the whitefly, Bemisia tabaci (Genn.) (Hemiptera: Aleyrodidae). Egypt. J. Biol. Pest Control 2020, 300, 1-9. [CrossRef]

129. Reyad, N.F. Empact of entomopathogenic fungi on whitefly, Bemisia tabaci in tomato crop in Egypt. Int. J. ChemTech Res. 2017, 10, 372-377.

130. Ortiz-Urquiza, A.; Keyhani, N.O. Action on the surface: Entomopathogenic fungi versus the insect cuticle. Insects 2013, 4, 357-374. [CrossRef] [PubMed]

131. Sandhu, S.S.; Sharma, A.K.; Beniwal, V.; Goel, G.; Batra, P.; Kumar, A.; Jaglan, S.; Sharma, A.K.; Malhotra, S. Myco-Biocontrol of insect pests: Factors involved, mechanism, and regulation. J. Pathog. 2012, 2012, 126819. [CrossRef]

132. Vega, F.E.; Meyling, N.V.; Luangsa-Ard, J.J.; Blackwell, M. Fungal entomopathogens. In Insect Pathology; Vega, F.E., Harry, K.K., Eds.; Elsevier Inc.: Amsterdam, The Netherlands, 2012; pp. 171-220.

133. Sinha, K.K.; Choudhary, A.K.; Kumari, P. Entomopathogenic Fungi. In Ecofriendly Pest Management for Food Security; Elsevier Inc.: Amsterdam, The Netherlands, 2016; pp. 475-505.

134. Augustyniuk-Kram, A.; Kram, A.J. Entomopathogenic fungi as an important natural regulator of insect outbreaks in forests (Review). In Forest Ecosystems-More Than Just Trees; IntechOpen: London, UK, 2012; pp. 266-294.

135. Agro, S.; Road, M.; Nadu, T. Entomopathogenic Fungi for the Control of Economically Important Whiteflies. J. Biol. Control 2007, 21, 29-36.

136. Meyling, N.V. Methods for Isolation of Entomopathogenic Fungi from the Soil Environment. Available online: https://orgprints.org/11200/ (accessed on 8 September 2020).

137. Mantzoukas, S.; Eliopoulos, P.A. Endophytic entomopathogenic fungi: A valuable biological control tool against plant pests. Appl. Sci. 2020, 10, 360. [CrossRef]

138. Butt, T.M.; Jackson, C.; Magan, N. Fungal Biological Control Agents: Progress, problems and potential. In Fungi as Biocontrol Agents: Progress, Problems and Potential; Butt, T.M., Jackson, C., Magan, N., Eds.; CAB International: Wallingford, UK, 2001; pp. 1-8.

139. Inglis, G.D.; Goettel, M.S.; Butt, T.M.; Strasser, H. Use of hyphomycetous fungi for managing insect pests. In Fungi as Biocontrol Agents; Butt, T.M., Jackson, C., Magan, N., Eds.; CAB International: Wallingford, UK, 2001; pp. 26-69.

(C) 2020 by the authors. Licensee MDPI, Basel, Switzerland. This article is an open access article distributed under the terms and conditions of the Creative Commons Attribution (CC BY) license (http://creativecommons.org/licenses/by/4.0/). 